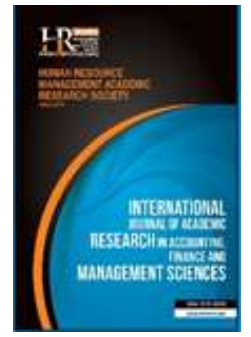

International Journal of Academic Research in Accounting, Finance and Management Sciences

Vol. 10, No.2, April 2020, pp. 65-75

E-ISSN: 2225-8329, P-ISSN: 2308-0337

(c) 2020 HRMARS

www.hrmars.com

To cite this article: Salaton, K. E., Gudda, P., Rukaria, G. (2020). Effect of Loan Default Rate on Financial Performance of Savings and Credit Cooperative Societies Innarok, County Kenya, International Journal of Academic Research in Accounting, Finance and Management Sciences 10 (2):65-75.

\title{
Effect of Loan Default Rate on Financial Performance of Savings and Credit Cooperative Societies Innarok, County Kenya
}

\author{
Kipai Elvis Salaton ${ }^{1}$, Patrick Gudda ${ }^{2}$, George Rukaria ${ }^{3}$ \\ ${ }^{1,2,3}$ Department of Business Management, Maasai mara University, Kenya, \\ ${ }^{1}$ E-mail: elviskipai@gmail.com (Corresponding author)
}

\begin{abstract}
In Kenya cooperative movement is one of the highly valued strategies used to enhance resource mobilisation and use. However, studies on factors that contribute to the performance of these cooperatives have produced mixed results that calls for further research in the same. This paper sought to further examine the effect of loan default rate on the financial performance of Savings and Credit Cooperative Societies in Narok County, Kenya. Financial performance was measured by use of return on asset and return on equity. Cross sectional research design was applied in this study. The target population comprised of 20 registered and active SACCOs in Narok County. Purpose sampling was used to select only 17 of the SACCOs which had been active for the six years period of the study. Secondary data from audited financial report between 2013 and 2018 was collected and used for the analysis. Both descriptive and inferential statistics were used to analyse the relationship between the variables. Statistical Package for Social Sciences version 23 and Microsoft Excel package were used as appropriate tool to analyse and present the results. The study hypothesis was tested at a 0.05 significant level. From the findings it was established that loan default rate had a positive statistical significant effect to financial performance of the SACCOs in Narok County. The null hypothesis on loan default rate was rejected as it had a p-value of less than 0.05.It was concluded that the rate of loan default among the SACCOs is a strong predictor of their financial performance. The study recommended that the SACCOs should put emphasis on ensuring members are able to repay their loans on time to enhance financial performance. The results are very significant and will go a long way to assist SACCOs to enhance their financial performance by re-assessing their loan advancement and recovery strategy among their members.
\end{abstract}

Key words Financial Performance, Loans Advanced, Loan Default, Loan Default Rate, Savings and Credit Cooperative Societies

\begin{tabular}{|c|c|c|}
\hline Received: & 08 May 2020 & (C) The Authors 2020 \\
\hline Revised: & 05 Jun 2020 & Published by Human Resource Management Academic Research Society (www.hrmars.com) \\
\hline $\begin{array}{l}\text { Accepted: } \\
\text { ed Online: }\end{array}$ & $\begin{array}{l}15 \text { Jun } 2020 \\
03 \text { Jul } 2020\end{array}$ & $\begin{array}{l}\text { This article is published under the Creative Commons Attribution (CC BY 4.0) license. Anyone may } \\
\text { reproduce, distribute, translate and create derivative works of this article (for both commercial and } \\
\text { non-commercial purposes), subject to full attribution to the original publication and authors. The full } \\
\text { terms of this license may be seen at: } h \text { ttp://creativecommons.org/licences/by/4.0/legalcode }\end{array}$ \\
\hline
\end{tabular}

\section{Introduction}

Savings and credit cooperative societies (SACCOs) provide financial services to many people in Kenya and many developing nations. However the demand for the service is big compared to the supply (Marwa \& Aziakpono, 2015). SACCO expansion is undermined by the lack of capital Financial intermediation is a great role played by saving and credit cooperative societies which is difficult when the need for money become more than the supply. The world Council of Credit Union suggested that SACCOs worldwide face similar challenges which brought about regulations that are remedial measures for future financial crisis (Olando \& Mbewa, 2012).

Savings and Credit Cooperative Societies have been recognized as critical avenues for economic growth in most countries of the world. SASSRA (2013) approximates that one billion people are affiliated 
with SACCOs across the globe as reflected in the composition of International Co-operative Alliance (ICA). Majority of countries that have achieved economic development have a cooperative sector featuring widespread vibrancy and dynamism (Olweny \& Shipho, 2011). SACCOs in Africa face similar financial challenges as the rest of the world which include both internal and external. Lack of adequate resources, capitals governance and technical knows how, and capitals are major internal challenges that prejudice financial performance of SACCOs. In addition SACCOs are affected by external factors which includes competition from the mainstream banks, government legislation and technology that has brought a great deal of globalization. SACCOs in Sub Saharan Africa (SSA) face the challenge of late payment, loan default, dormant assets, low interest rates, illiquid assets, huge cost of operation including salaries for staff and losses incurred from other SACCOs businesses. These factors are a great impediment to Sacco's financial performance (Meyer, 2015)

Rapid growth of SACCOs that characterized African countries such as South Africa, Kenya and Rwanda have enhanced the substantial growth of economies due to their focus on provision of financial services for benefit of start-ups (Mokua,2015). According to Chahayo et al. (2013) SACCOs in Kenya are facing a challenge related to both financial and governance. Besides SACCOs performance has been affected by loan default which is as a result of assessment and management of financial risk, poor investments decision, negative cash liquidity which make it difficult to advance loans and pay dividends, and poor investment decisions (Olando \& Mbewa, 2012). This paper focused on providing additional literature to enhance the understanding of the effect of loan default rate on financial performance of SACCOs in Narok County.

I.Financial performance refers to how effectively a firm utilizes limited resources to produce resources which yield maximum revenue (Nwaolisa \& Chijindu, 2016). Financial performance of a SACCO is significant as it reveals the sustainability of a SACCO (Swain \& Partnaik, 2013). It is an indication of whether a firm is a going concern or not. This a major factor in the investors decision of whether to invest in a firm or not. The proxies used in determining a firm performance are ROA and ROE (Nwaolisa \& Chijindu, 2016).Return on Assets is the ratio of total assets to the profit generated by a firm. A high level of Return on Assets is an indication of a firm is efficiency in assets utilization. Sebhatu (2011) use ROA to evaluate profitability of savings and credit cooperative societies (SACCOs) in Ethiopia. High rate of ROE indicate high levels of performance by the SACCO. ROE is the best measure as it indicates the return of its unit holder.

A study by Mwangi (2016) established that there were approximately 5,122 registered SACCOs in Kenya by 2016 . Out of these $44 \%$ were active SACCOs. It was further established that most active SACCOs were mainly located in the urban areas with 150 are rural Saccos (commodity based) while the rest are Urban SACCOs (employee based). All Saccos operate Back Office Service Activities and have been able to mobilize over Kshs 230 billion, which is about 31 percent of the national saving and granted loans to the tune of Kshs 210 billion (Ministry of Cooperative Development and Marketing, 2010). SACCOs have registered tremendous growth since mid-1970s and have currently achieved an average growth rate of 25 percent per year in deposits and assets. SACCOS have grown tremendously and currently have about 3.7 million members. It is also noted that SACCOs contribute up to $45 \%$ of the GDP in Kenya with the sub sector having mobilized over Ksh 200 billion deposits and assets totalling to Ksh210 billion (MCD \&M 2010).

The total number of registered SACCOs in Narok County is 20 with only 17 active (Directorate of cooperative development Narok County, 2017). Total membership in the County is approximately 7845; total assets are Kes 926,670,186; total shareholding Kes 16,864,765; total members deposit is Kes $577,667,072$; total loan advanced is Kes $656,275,092$ and total turnover is $70,119,096$. Performance of Cooperatives in Narok County is so worrying with only 17 of the registered SACCOs being active (KNA 2017).The in 2016 the SACCOs in Narok were seen to earn Sh.42.5million only when the estimated earnings were to be Sh.3Billion annually (KNA 2017). However, due to lack of capital the SACCOs in Narok County are lagging behind compared to other counties. It is in this context that the study would find out the how loan default, Membership size, dividend payout and SACCOs investments influence the performance of SACCOs in Narok County, Kenya. 


\subsection{Statement of the Problem}

The SACCO sector in Kenya is the major of all in Africa. SACCO plays a fundamental role in financial service delivery. Pooling of capital for investments and wealth creation is one of the major roles played by SACCOs (Ratemo, 2015). Through domestic savings SACCOs spur economic growth. On the other hand SACCOs cannot successfully carry out their mandate due to lack of sufficient internal capital, high cost of external debt, under capitalization and strict capital adequacy requirements (Mwende \& Kalio, 2014; Kivuvo \& Olwenyi 2014; Onyango, 2016). SACCOs in Narok County are performing poorly due to various internal and external related factors of which loan default, is just but one of them (KNA, 2017). The collapse of some SACCOs such as Jua Kali SACCO in Narok and lose of membership among other SACCOs such as the giant Good hope SACCO a fact that undermines the going concern of SACCOs (KNA, 2017). This is a situation that pervades many SACCOs not just in Narok County but across the globe. Thus, the performance of SACCOs has been an issue of major concern to various stakeholders including the members, regulators and investors. However, for both existing and potential stakeholders to be able to make more informed decisions there is need to assess the financial performance of these SACCOs over a period of time to reveal the trend of performance. This study therefore sought to evaluate the performance of SACCOs in relation to loan default rate, over a six years period (2013-2018) among Saccos in Narok County?

\subsection{Objectives of the Study}

The general objective of the study is to evaluate the effect of loan default rate on financial performance of SACCOs in Narok County. Specifically the study sought to determine the effect of loan default rate on financial performance of SACCOs in Narok County.

\subsection{Hypotheses of the Study}

The study sought to ascertain the following hypotheses:

$\mathrm{H}_{01}$ : There is no significant relationship between loan default rate and financial performance of SACCOs in Narok County.

\subsection{Significance of the Study}

The findings would be used by board of directors and chief executive of Sacco's in developing saving mobilization and lending strategies. The study will also add value to existing literature on loan default and the financial performance of SACCOs. Future researchers also in this line of study would have the opportunity to use the findings to further their research. SASRA can find useful information that would help in formulating policies that would lead to regulating of SACCOs. Future researchers will use the findings to inform their research and expand on the empirical review of literature.

\section{Literature review}

\subsection{Theoretical Framework}

This study was guided by four theories, credit risk theory, organizational theory, Trade off Theory and Bird in Hand.

\subsection{Conceptual Framework}

The Conceptual Framework in figure 1 is conceived as a functional relationship between loan default rate and financial performance as the dependent variable. The financial performance will be gauged by relating net income to total assets. 


\begin{tabular}{|l|c|}
\multicolumn{1}{c|}{ Independent variable } & \multicolumn{1}{c|}{ Dependent variable } \\
\hline Loan default rate & Financial Performance \\
-Amount of Loans dispersed & \\
-Amount of Loan defaulted & - Default rate $=$ loan defaulted/loan dispersed \\
\cline { 2 - 3 } & -Return on Assets $=$ Total Income/Total Assets \\
-Return on Equity = Total Income/Total Equity
\end{tabular}

Figure 1. Conceptual Framework

The role of credit is to bridge the gap between enterprise owners' financial assets and the required financial assets of enterprises. Due to persistence of this imbalance enterprises are required and compelled to acquire credit. As the SACCO's are increasing in number in Kenya, access to credit is not difficult but repayment is never $100 \%$.Also, there are no stringent policies set by SACCOs in the country that regulate issuing of loans and collecting payments. Besides, limited credit appraisal poses a hitch in that SACCOs in Kenya carry out an inadequate financial assessment of clients and their guarantors leading to disbursing of loans to credit unworthy members who eventually default (Wanjiru \& Muturi, 2016). There are inadequate provisions to deal with willful defaulters although the public sector banks have not been aggressive in implementing. In his report Yashwant (2014), was concerned about the mounting non-performing assets in the corporate lending segment as compared to other sectors. On the other hand Ikua (2015) asserted that most financial institutions have been characterized by managerial failures because of their inability to manage the rising non-performing assets and their inadequate credit monitoring and control mechanism. Management of loan defaulters extends to insuring loans against default and requiring collateral as a surety that the loan will be paid. SACCO's with effective strategies for managing loan defaulters are believed to have high chances of excellent financial performance while SACCOs with ineffective defaulter management strategies may be prone to high financial risks (Miriti, 2014).

\subsection{Loan Default and SACCO Financial Performance}

Clement and Martin (2012) asserted that in many countries recovery rate and collateral values on defaults may be volatile and always go down due to increase in the rate of defaults in recession. The focus on non-payment examination has been changed by increased number of researched on the subject of estimation of recovery rate and the relationship between recovery rate and default. In Kiambu County a study was conducted by Wanjiru \& Muturi (2016) on the subject of financial performance. The study hypothesized that Sacco's financial operation was determined by loan default policy. Descriptive research design was used whereby secondary data was collected from audited financial statements for a period of 5 years 2010-2014. Descriptive and inferential statistics were used in data analysis. Wangai et al. (2012) on the impact of nonperforming loans on performance of micro finance institutions in Kenya. Descriptive research design was adopted. Moreover census was applied on selected 66 credit management staffs of micro finance banks in Nakuru. Questionnaires were used to collect primary data. Descriptive and inferential statistics was used to analyse the data. The study established that there is un constructive and significant association between nonperforming loans and financial performance. The study recommended that microfinance banks should develop measures to reduce the rate of loan default by critically analysing potential borrowers to judge their credit worthiness and the same applies to Sacco's members. However Primary data are subject to manipulation hence there was need to use secondary data which are more conclusive as they are obtained from the organization financial statements.

In Ethiopia a study by Yuvaraj \& Wondem (2013) to analyse Sacco's performance used a descriptive design and secondary data was collected from annual audited financial statements for a period of 4 years from 1998 to 2001. Data was analysed using descriptive research analysis and the results indicated that SACCOs were unhealthy because of escalating levels of loan default. The inferential statistics should have been applied to establish a casual effect relating independent variables and the dependent variable. While a study by Muriuki (2010) in Meru County on factors affecting performance of SACCOs. Governance was identified as a major issue that affected financial performance of SACCOs. However governance is a nonfinancial factor and this study used audited financial reports to gauge Sacco's financial performance. Most 
of these studies have focused mainly on SACCOs is large urban setting and have mainly been descriptive in nature with only a few using the cross sectional design where data is collected from different Sacco's over a longer period of time to establish the trends in the performance of the SACCOs. This is a gap that the current study sought to fill in order to add to the existing literature.

\section{Methodology of research}

A cross sectional survey research design was used since the study collected secondary data from different SACCOs aand is appropriate in establishing to establishing statistical relationships among variables through complex statistical modeling (Khalid et al., 2012).

The study targeted only the 20 registered and active SACCOs operating in Narok County between the years 2013 to 2018. However, the researcher used criterion purposive sampling where only 17 of the SACCOs that were operating in Narok County between 2013 to 2018 were considered for the study.

Secondary data was collected from audited and published financial statements of the 17 SACCOs available from the main offices of the SACCOs. From each year data on loans advanced and loan defaulted were extracted for all the SACCOs under study. Financial performance was measured by Return on Equity and Return on Assets for each SACCO where, data on profit after tax, total assets and total equity were collected.

Data was analysed using both descriptive and inferential statistics. Descriptive statistics of mean and standard deviation was used to assess the magnitudes of the responses for easy comparison and interpretation. The inferential analysis constituted correlation coefficient for assessing the relationship between the variables, analysis of variance (ANOVA) used to evaluate the effectiveness of the model to explain the relationship between the variables while regression analysis was used to evaluate the percentage contribution of the independent variables to the performance of the SACCOs. The hypotheses of the study were tested for significance at a $p$ value of 0.05.SPSS and Ms Excel was used as tools for data analysis. The results were presented using figures and tables. Simple linear Regression model was used to test the significance of the influence of the independent variables on the dependent variable. The linear regression model is as presented.

$Y=\alpha+\beta 1 X_{1}+e$

Where:

$\mathrm{Y}=\mathrm{A}$ measure of Financial Performance based on ROA and ROE $\alpha=$ Constant term

$\beta=$ Beta coefficient; $X_{1}=$ Loan default rate; $\mathrm{e}=$ Error term.

Return on Asset $=$ Total Profit $/$ Total Assets

Return on Equity $=$ Total Profits/Total Equity

Loan default rate $=$ Non-performing loan/total loan advance

The test of significance was performed at 95\% level of confidence using Analysis of Variance (ANOVA) and the $\mathrm{F}$ - tests used to determine the significance of the regression. Correlation analysis was carried out to find the direction of the relationship between performance and Loan default ratio. The coefficient of determination, $\mathrm{R}^{2}$, was used to determine how much variation in dependent variable is explained by the independent variables included in the model.

\section{Findings}

This study sought to find out the mean and standard deviation of the various indicators that were under study in order to understand the performance of the SACCOs for the six years between the years 2013 to 2018. The study collected data from the 17 Sacco's which was used for the analysis. The study sought to find out the effect of loan default rate on the performance of the SACCOs operating in Narok County. In order to assess this effect the researcher sought to find out the amount of loans advanced by the SACCOs and the amount of loans defaulted in the same period in order to determine the default rate and how it affected the performance of the SACCOs. The amount of loans advanced to the members for the study period was presented in Table1. 
The results show that most of the Sacco $78.4 \%$ had advanced loans to their members of less than Ksh $10,000,000$ over the six years period. Only $17.6 \%$ of the SACCO had advanced over $40,000,000$ while $2.9 \%$ had lent out between $10,000,000$ to $20,000,000$. This implies that most of the SACCOs had advanced a total of less than ksh 10,000,000 in loans for the period of the study. The study also presented the amount of loans defaulted by the members between the study period. The results are presented in table 2 . The results shows that majority of the SACCOs $85.3 \%$ indicated that over the six years the amount of loan defaulted was less than Kshs 500,000, while $13.7 \%$ indicated that over kshs 2,000,000 loans had been defaulted by the borrowers over the six years. This implies that majority of the SACCOs had a loan default rate ranging from kshs 0-500,000 each year in the six years of the study.

Table 1.Total Loan advanced

\begin{tabular}{|c|c|c|c|c|c|c|c|c|}
\hline \multirow{2}{*}{ ‘000’ } & & \multicolumn{6}{|c|}{ YEARS } & \multirow{2}{*}{ Total } \\
\hline & & 2013 & 2014 & 2015 & 2016 & 2017 & 2018 & \\
\hline \multirow{2}{*}{ Less than 10,000} & Count & 14 & 14 & 14 & 14 & 13 & 11 & 80 \\
\hline & $\%$ & $82.4 \%$ & $82.4 \%$ & $82.4 \%$ & $82.4 \%$ & $76.5 \%$ & $64.7 \%$ & $78.4 \%$ \\
\hline \multirow{2}{*}{$10001-20000$} & Count & 0 & 0 & 0 & 0 & 1 & 2 & 3 \\
\hline & $\%$ & $0.0 \%$ & $0.0 \%$ & $0.0 \%$ & $0.0 \%$ & $5.9 \%$ & $11.8 \%$ & $2.9 \%$ \\
\hline \multirow{2}{*}{$20001-30000$} & Count & 0 & 0 & 0 & 0 & 0 & 1 & 1 \\
\hline & $\%$ & $0.0 \%$ & $0.0 \%$ & $0.0 \%$ & $0.0 \%$ & $0.0 \%$ & $5.9 \%$ & $1.0 \%$ \\
\hline \multirow{2}{*}{ More Than 40000} & Count & 3 & 3 & 3 & 3 & 3 & 3 & 18 \\
\hline & $\%$ & $17.6 \%$ & $17.6 \%$ & $17.6 \%$ & $17.6 \%$ & $17.6 \%$ & $17.6 \%$ & $17.6 \%$ \\
\hline \multirow{2}{*}{ Total } & Count & 17 & 17 & 17 & 17 & 17 & 17 & 102 \\
\hline & $\%$ & $100.0 \%$ & $100.0 \%$ & $100.0 \%$ & $100.0 \%$ & $100.0 \%$ & $100.0 \%$ & $100.0 \%$ \\
\hline
\end{tabular}

Table 2. Amount of Loans Defaulted

\begin{tabular}{|c|c|c|c|c|c|c|c|c|}
\hline \multirow{2}{*}{\multicolumn{2}{|c|}{$‘ 000 ’$}} & \multicolumn{6}{|c|}{ YEARS } & \multirow{3}{*}{$\begin{array}{c}\text { Total } \\
87\end{array}$} \\
\hline & & 2013 & 2014 & 2015 & 2016 & 2017 & 2018 & \\
\hline \multirow{2}{*}{$0-500$} & Count & 15 & 15 & 15 & 14 & 14 & 14 & \\
\hline & $\%$ & $88.2 \%$ & $88.2 \%$ & $88.2 \%$ & $82.4 \%$ & $82.4 \%$ & $82.4 \%$ & $85.3 \%$ \\
\hline \multirow{2}{*}{$1501-2000$} & Count & 0 & 0 & 0 & 0 & 0 & 1 & 1 \\
\hline & $\%$ & $0.0 \%$ & $0.0 \%$ & $0.0 \%$ & $0.0 \%$ & $0.0 \%$ & $5.9 \%$ & $1.0 \%$ \\
\hline \multirow{2}{*}{ Over 2000} & Count & 2 & 2 & 2 & 3 & 3 & 2 & 14 \\
\hline & $\%$ & $11.8 \%$ & $11.8 \%$ & $11.8 \%$ & $17.6 \%$ & $17.6 \%$ & $11.8 \%$ & $13.7 \%$ \\
\hline \multirow{2}{*}{ Total } & Count & 17 & 17 & 17 & 17 & 17 & 17 & 102 \\
\hline & $\%$ & $100.0 \%$ & $100.0 \%$ & $100.0 \%$ & $100.0 \%$ & $100.0 \%$ & $100.0 \%$ & $100.0 \%$ \\
\hline
\end{tabular}

The loan default rate was computed using the formula;

Loan default rate $=\underline{\text { Total amount of loan advanced }}$

Total amount of loans defaulted

The total amount of loans advanced every year, loans defaulted and default rates were presented in Table 3.

Table 3. Loan default rate

\begin{tabular}{lcccccccc}
\hline \multicolumn{1}{c}{ Year } & Y2013 & Y2014 & Y2015 & Y2016 & Y2017 & Y2018 & MEAN & STD DEV \\
\hline Total loans advanced (000) & 631,401 & 687,955 & 720,622 & 805,977 & 875,805 & 949,747 & 467,151 & 120,611 \\
Total loans default (000) & 10,427 & 11,973 & 17,244 & 23,531 & 27,427 & 27,458 & 11,806 & 7,566 \\
Mean loan default (000) & 613 & 798 & 1,149 & 1,384 & 1,613 & 1,615, & 7,174 & 421 \\
Mean loan dispersed (000) & 37,141 & 45,864 & 48,041 & 47,410 & 51,518 & 55,867 & 285,842 & 6,266 \\
Default rate & 0.017 & 0.018 & 0.024 & 0.029 & 0.031 & 0.029 & 0.025 & 0.0064 \\
\hline
\end{tabular}

The results show that the mean amount of loans advanced to the members was ksh 467,151, 000 over the six years study period while the mean of the loans defaulted was over the same period was kshs $7,566,000$. The default rate on average was $2.5 \%$ of the total loans advanced over the study period with the highest default rate occurring between the year 2016 and 2017 at $2.9 \%$ and $3.1 \%$ respectively. This shows 
that the loan default rate has been on the upward trend between the years 2013 to 2018 as shown in figure 2.

This implies that most SACCOs had experienced loan default among their members and this could be a contributing factor to the performance of the SACCOs in Narok County as the rate of default increased from 0.017 to high of 0.031 . This agrees with the finding of Koskei and Naibei (2017) who established that the performance of the SACCOs depends to a great extent on the ability of the members to manage their loans and hence reduce the rate of loan default. The ability of member to honour their loan obligation is influenced by member's loyalty which is influenced by incentives such as lending interest rates.

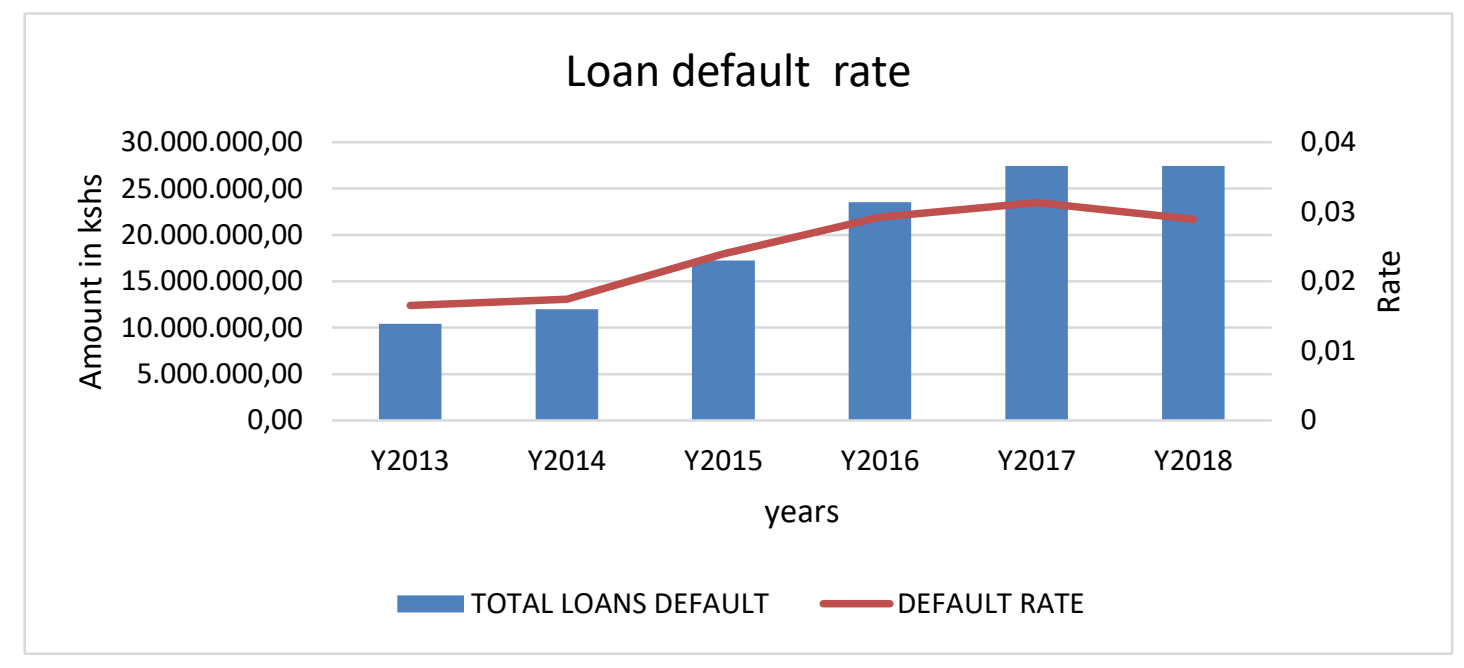

Figure 2. Loan default over the years

Table 4. Total Income after Tax

\begin{tabular}{|c|c|c|c|c|c|c|c|c|}
\hline \multirow{2}{*}{\multicolumn{2}{|c|}{$‘ 000 ’$}} & \multicolumn{6}{|c|}{ YEARS } & \multirow{2}{*}{ Total } \\
\hline & & 2013 & 2014 & 2015 & 2016 & 2017 & 2018 & \\
\hline \multirow{2}{*}{$0-500$} & Count & 15 & 13 & 14 & 13 & 11 & 11 & 77 \\
\hline & $\%$ & $88.2 \%$ & $76.5 \%$ & $82.4 \%$ & $76.5 \%$ & $64.7 \%$ & $64.7 \%$ & $75.5 \%$ \\
\hline \multirow{2}{*}{$501-1000$} & Count & 0 & 1 & 0 & 1 & 2 & 2 & 6 \\
\hline & $\%$ & $0.0 \%$ & $5.9 \%$ & $0.0 \%$ & $5.9 \%$ & $11.8 \%$ & $11.8 \%$ & $5.9 \%$ \\
\hline \multirow{2}{*}{$1001-1500$} & Count & 0 & 1 & 0 & 0 & 1 & 0 & 2 \\
\hline & $\%$ & $0.0 \%$ & $5.9 \%$ & $0.0 \%$ & $0.0 \%$ & $5.9 \%$ & $0.0 \%$ & $2.0 \%$ \\
\hline \multirow{2}{*}{$1501-2000$} & Count & 0 & 0 & 1 & 1 & 0 & 0 & 2 \\
\hline & $\%$ & $0.0 \%$ & $0.0 \%$ & $5.9 \%$ & $5.9 \%$ & $0.0 \%$ & $0.0 \%$ & $2.0 \%$ \\
\hline \multirow{2}{*}{ OVER 2000} & Count & 2 & 2 & 2 & 2 & 3 & 4 & 15 \\
\hline & $\%$ & $11.8 \%$ & $11.8 \%$ & $11.8 \%$ & $11.8 \%$ & $17.6 \%$ & $23.5 \%$ & $14.7 \%$ \\
\hline \multirow{2}{*}{ Total } & Count & 17 & 17 & 17 & 17 & 17 & 17 & 102 \\
\hline & $\%$ & $100.0 \%$ & $100.0 \%$ & $100.0 \%$ & $100.0 \%$ & $100.0 \%$ & $100.0 \%$ & $100.0 \%$ \\
\hline
\end{tabular}

The results show that majority of the SACCOs $75.5 \%$ had a total income after tax of kshs of upto 500,000 , followed by $14.5 \%$ who had an total income after tax of over kshs $20,000,000,5.9 \%$ had income after tax of between kshs 500,000 to $1,000,000$ while the rest $2 \%$ had an income after tax of between kshs $1,000,000$ and 1,500,000 and a similar number had total income after tax of between ksh 1,500,000 and $2,000,000$. The performance of the SACCOs was then computed based on the above data. The ROA and ROE was computed and presented in table 5. The mean of the two indicators was used to express the performance of the SACCOs which was required for the purpose of determining the correlation and regression of the variables. The results show the total assets, total equity and total income for each year from 2013 to 2018. The mean assets are estimated at Ksh 971,802,000, showing an upward trend between the study periods settling at a high of kshs 1,176,979,000 by 2018. 
Table 5. Return on Assets and Return on Equity

\begin{tabular}{lcccccccc}
\hline & $\mathbf{2 0 1 3}$ & $\mathbf{2 0 1 4}$ & $\mathbf{2 0 1 5}$ & $\mathbf{2 0 1 6}$ & $\mathbf{2 0 1 7}$ & $\mathbf{2 0 1 8}$ & MEAN & STDV \\
\hline Total Assets(000) & 759,083 & 848,188 & 907,610 & $1,033,565$ & $1,105,298$ & $1,176,979$ & 971,802 & 160,232 \\
Total Equity (000) & 102,481 & 108,303 & 118,340 & 108,493 & 109,223 & 109,354 & 109,366 & 5,096 \\
Total Income after & & & & & & & & \\
Tax (000) & 80,393 & 91,219 & 94,737 & 100,337 & 94,588 & 89,626 & 91,817 & 6,700 \\
ROA & 0.106 & 0.107 & 0.104 & 0.097 & 0.086 & 0.076 & 0.094 & 0.041 \\
ROE & 0.784 & 0.842 & 0.800 & 0.925 & 0.866 & 0.819 & 0.839 & 1.315 \\
\hline
\end{tabular}

The mean equity is estimated at kshs $109,366,000$ and the mean income after tax is kshs $6,700,000$. The return on assets showed a decline between 2013 and 2018 averaging at 0.094 while the return equity fluctuates over the study period increasing to a high of 0.925 and settling at 0.839 in 2018 . This implies that the performance of SACCOs showed a decline in the last six years of the study. The mean of ROA and ROE was computed to assess the performance of the SACCOs. By combining the two ratios it is possible to assess the trend as shown in figure 3.

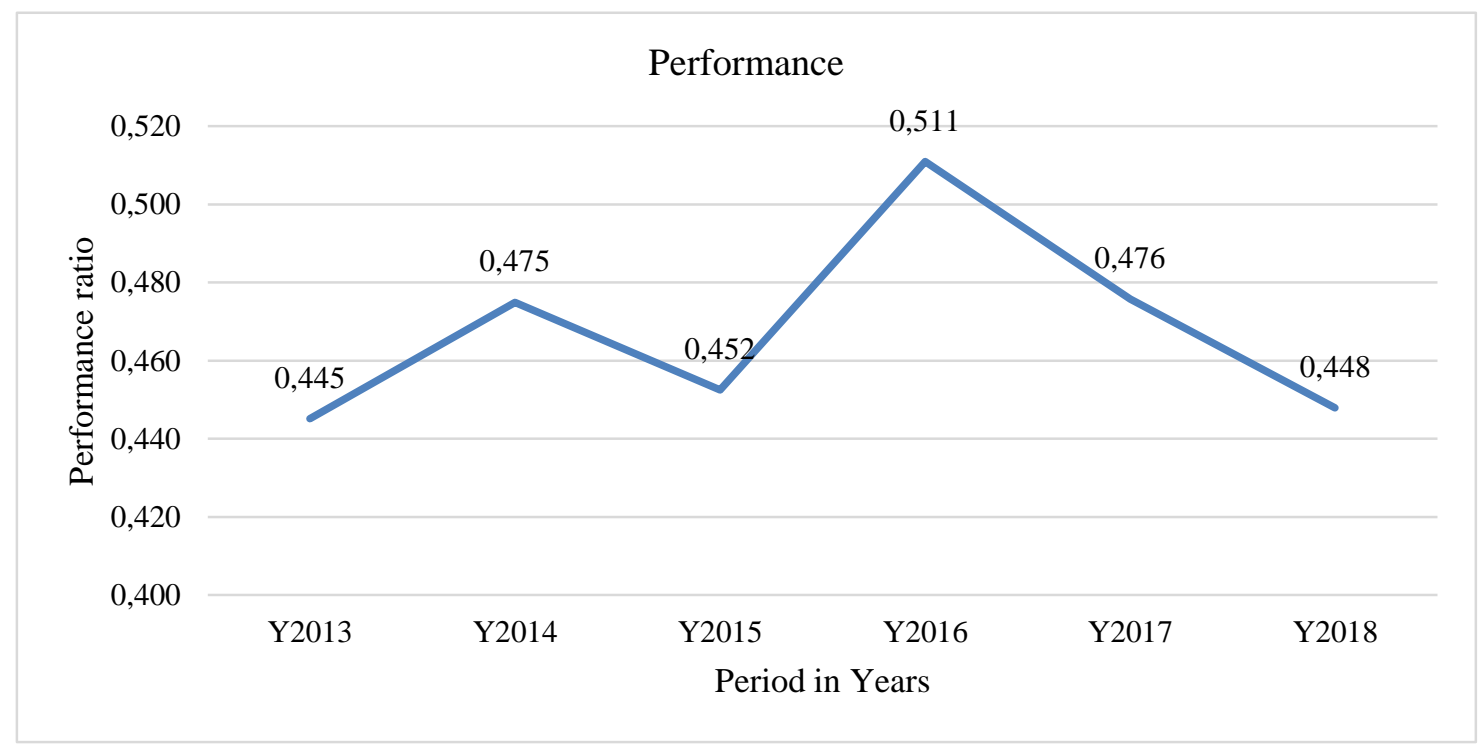

Figure 3.Mean performances of the Sacco's

The results show that the maximum mean performance of the SACCOs was 0.511in the year 2016 and the minimum was 0.445 in the year 2013. The figure shows that the level of performance of SACCOs is not stable a fact that can be attributed to the other selected factors in the study. The reduction in the membership and return on equity levels are believed to have had an effect on the performance of the SACCOs during the year of study. Apart from dividend payout which indicated a steady increase the other factors were seen to fluctuate year after years and hence might have contributed to the fluctuation in the performance of the SACCOs. This indicates that there was a sharp increase in the performance of the SACCOs in 2016 which again declaimed to a value of 0.448 in 2018. This might be attributed to the decline total income after tax which affected the ROA and the ROE of the SACCOs.

\section{Correlation Analysis}

The results further sought to establish how these factors correlate with the performance of the firm. It was important to analyze how these selected determinants affect the performance of SACCOs. In order to evaluate whether there was correlation between the independent and independent variable SPSS was used to correlate the independent and the dependent variable. The results are presented in table 6 . The results in table 6show that there is a positive and very significant correlation between loan default rate and performance of the SACCOs in Narok county $(r=.372 ; \mathrm{P}$ value $=0.000)$. These findings justify earlier findings such as Gekara \& Joseph (2013) who indicated that the performance of SACCOs measured by ROA ad ROE is influenced by among other factors the rate of loans default by the members. 
Table 6. Correlations Between loan default rate and the performance of SACCOs

$\begin{array}{cccc} & \text { Pearson Correlation } & 1 & .372^{* *} \\ \text { Performance } & \text { Sig. (2-Tailed) } & & .000 \\ & \mathrm{~N} & 102 & 102\end{array}$

*. Correlation is significant at the 0.01 level (2-tailed).

\section{Simple linear Regression Analysis}

The $\mathrm{R}$ was used to represent the correlation coefficient between the variables; $\mathrm{R}^{2}$ is a measure of how much of the variability in the performance is accounted for by the predictor variables. The results are presented in table 7.

Table 7. Regression Model of the Relationship between Predictor Variables and the Performance

\begin{tabular}{cccccccccc}
\hline \multirow{2}{*}{ Model } & \multirow{2}{*}{$\mathrm{R}$} & $\mathrm{R}$ Square & $\begin{array}{c}\text { Adjusted R } \\
\text { Square }\end{array}$ & $\begin{array}{c}\text { Std. Error of } \\
\text { the Estimate }\end{array}$ & $\begin{array}{c}\text { R Square } \\
\text { Change }\end{array}$ & F Change & df1 & df2 & Sig. F Change \\
\hline 1 & $.372^{\mathrm{a}}$ & .139 & .130 & .676 & .139 & 16.099 & 1 & 100 & .000 \\
\hline
\end{tabular}

a. Predictors: (Constant), LOAN DEFAULT RATE

The model summary shows that the value of $R=0.372^{\mathrm{a}} ; \mathrm{p}$ value $=0.000 ; \mathrm{F}$ value $=16.099$ and $R^{2}=$ 0.139 , this indicates that the correlation coefficient between the predictor variables (Loan Default and the outcome (financial performance) is positive and statistically significant since the $P$ value is less than the critical value of 0.05 . The $R^{2}$ value of 0.139 implies that the predictor variable combined account for only $13.9 \%$ of the variation in financial performance of SACCOs in NarokCounty. This supports the results of Karagu \& Okibo (2014) and Oloo (2013) who also established that there is a very significant effect between various predictor variables and the performance of the SACCOs.

The study further tested whether the model is significantly better at predicting the outcome or not. To test for this aspect the analysis of variance (ANOVA) was computed where the $\mathrm{F}$ ratio which represents the ratio of improvement in prediction was established. The ratio was considered to be a significant predictor of the performance if the $P$ value was less than 0.05 . The model was represented in table 8 .

Table 8. ANOVA ${ }^{\mathrm{a}}$

\begin{tabular}{ccccccc}
\hline & Model & Sum of Squares & df & Mean Square & F & Sig. \\
\hline \multirow{2}{*}{1} & Regression & 7.360 & 1 & 7.360 & 16.099 & $.000^{\mathrm{b}}$ \\
& Residual & 45.718 & 100 & .457 & & \\
& Total & 53.078 & 101 & & & \\
\hline
\end{tabular}

A. Dependent Variable: Performance

B. Predictors: (Constant), Loan Default Rate

The results shows that the model is a very strong predictor of the relationship between the predictor variables and financial performance of the SACCOs in Narok county given that the F value (16.099) as indicated on the ANOVA table was much higher than the critical $F$ value at $\mathrm{df}(1 ; 100)$ which is 2.327 and the $p$ value is less much than $0.05(P=0.000)$ which indicates that the model is a good predicator of financial performance of SACCOS in Narok county. The study also sought to establish whether the relationship between the variables was significant or not and whether positive or negative. The results are presented in table 9.

Table 9. Coefficients

\begin{tabular}{llccccc}
\hline & \multirow{2}{*}{ Model } & \multicolumn{2}{c}{ Unstandardized Coefficients } & \multicolumn{2}{c}{ Standardized Coefficients } & t \\
& & B & Std. Error & Sig. \\
\hline \multirow{2}{*}{1} & (Constant) & 1.443 & .185 & & 7.781 & .000 \\
& Loan Default Rate & .310 & .077 & .372 & 4.012 & .000 \\
\hline
\end{tabular}

a. Dependent Variable: Performance 
The results presented in the table 9indicate that the degree to which the predictor values affect the outcome financial performance when all other factors are held constant is 1.443 . If the t-statistic associated with the $\beta$ value is between -2 and +2 then the null hypothesis of no statistical significance between the predictor variable and the outcome is accepted. It is also important to note that when the $P$ value is less than 0.05 then it means that the predictor value is making a significant contribution to the model and the $t$ value will be either less than -2 or more than +2 .

This relationship was statistically significant given that the $(\beta=0.310$; $\mathrm{t}$ value $=4.012, \mathrm{p}$ value $=$ 0.000 ) hence it was a strong contributor to financial performance of the Sacco's in Narok county.

Analysis of data was based on multiple linear regressions as specified below.

Financial performance $=1.443+0.310 \mathrm{X}_{1}+0.185$

Defaulting loans positively affected financial performance. This means that $1 \%$ increase in loans default rate results in $53.2 \%$ improvement of financial performance of SACCOs in Narok County. It is therefore noted that the selected determinants of financial performance of SACCOs in Narok county have an influence and hence will determine whether the SACCOs will perform or not.

The summary is done in line with the objectives of the study based on the output of the descriptive and inferential statistical analyses guided to test the research hypothesis of the study.

\section{Loan default Rate and the Financial Performance}

The first objective of the study was to evaluate the effect of loan default rate on financial performance of SACCOs in Narok County. These methods included descriptive statistics, correlation analysis and regression analysis. The findings indicated that most SACCOs $78.4 \%$ had advanced loan of less than ksh 10 million over the six years of the study, with majority $85.3 \%$ having recorded a loan default value of less than ksh 500,000. The results further indicated that the highest loan default rate was in 2017 of which 3.1 $\%$ of the loans advanced were defaulted.Further analysis to test relationship between loan default rate and the performance of the SACCO indicated that there was a positiveand statistically significant relationship between loan default rate and financial performance of the SACCOs in Narok County. Therefore the null hypothesis there is no significant relationship between loan default rate and performance of SACCOs in Narok County was rejected and the alternative hypothesis therefore accepted that loan default rate had a statistically significant relationship with performance of the SACCOs in Narok County.

\section{Conclusions, recommendations}

In view of the aforementioned analysis, this study concludes that the combined effect of loan default rate, is a significant contributor of financial performance of SACCOs in Narok County.

The study recommends that Sacco's need to put more efforts in managing their loan default rates as it has a very significant influence on their financial performance. The rate of loan default was noted to have the highest significant influence on financial performance and therefore.

\subsection{Limitation of the Study and suggested Areas for Further Research}

The study only used quantitative methodology for statistical analysis. The study also focused only on active SSACCOs in Narok County between the years 2013 to 2018. The results are therefore only fi to explain the situation in Narok County and cannot be generalized. Arising from the findings and the gaps in the study, a replica study is recommended for a broader coverage of SACCOs in other regions in order to test whether the conclusions of this study will hold true. There is also need for another study to be conducted to test the effect of other factors which were not considered in current study to establish their effect on financial performance of the SACCOs.

\section{References}

1. Chahayo, S. A., Bureti, P., Juma, Maende, M. C., Douglas, M., \& Aketch, R. A. (2013). Analysis of Financial Mismatch in cooperative societies in Kakamega County, Kenya. International Journal for management science and technology Vol. 1 Issue 5. 
2. Ikua, K. S. (2012). Effect of credit management practices on financial performance of savings and credit cooperative societies in the Hospitality Industry in Nairobi (Doctoral dissertation, Master Thesis, University of Nairobi. 66pp).

3. Karagu, J. M., \& Okibo, B. (2014). Financial factors influencing performance of savings and credit cooperative Organization in Kenya. International Journal of Academic Research in Accounting, Finance and Management Sciences.Vol.4, pp. 291-302.

4. Khalid, K., Abdullah, H. H., \& Kumar M, D. (2012). Get along with quantitative research process. International Journal of Research in Management.

5. Kivuvo, R. M., and Olweny, T. (2014)."Financial performance analysis of Kenya's Sacco sector using the Altman Z-score model of corporate bankruptcy." International Journal of Business and Social Science Vol. 5(9)1.

6. Koskei, R. K., Naibei, I. K. (2017). Determinants of member loyalty among SACCOs: A survey of selected SACCOs: A survey of selected SACCOs in Kericho County, Kenya. International Journal of Economics, Commerce and Management, 5(7), 637-654.

7. Marwa, N., \& Aziakpono, M. (2015). Financial sustainability of Tanzanian saving and credit cooperatives. Journal of Social Economics.

8. Meyer, R. L. (2015). Financing agriculture and rural areas in sub-Saharan Africa: Progress, challenges and the way forward.

9. Miriti, J. (2014). Factors influencing financial performance of savings and credit cooperative societies: A case of Capital SACCO, Meru County, Unpublished MSc Project, Nairobi: University of Nairobi.

10.Muriuki, M. (2010). Factors affecting Sacco performance in Meru South district: a case of TharakaNithi Teachers Sacco. Unpublished MBA project, University of Nairobi.

11.Mwangi, E. (2015). Factors influencing performance of Saccos in Kenya: A case of UNAITAS Sacco (Doctoral dissertation, The Management University of Africa).

12. Mwenda, M., \& Kalio, A. (2014). Determinants of capital structure in savings and credit societies in Kenya: A case of cooperatives in Nakuru County. International Journal of Science and Research, 3 (10), 2413-2417.

13.Nwaolisa, E., \& Chijindu, A. (2016). The Impact of Financial Structure on Firm Performance: A Study of Nigeria Agricultural and Healthcare Sector. Archives of Current Research International, 4(1), 1-26. http://doi.org/10.9734/ACRI/2016/24570

14.Olando, C. O., and Mbewa M. O. (2012). The Contribution of SACCO Financial Stewardship to Growth of SACCOS in Kenya. International Journal of Humanities and Social Science, 3(17), 112-132.

15.Oloo, O. (2013). An Analysis of the Socio-Economic Impact of Co- operatives and their Institutional Context in Kenya, International Cooperative Alliance and the Canadian Cooperative Association.

16.Olweny, T., \& Shipho, T. M. (2011). Effects of Banking Sectoral Factors on the Profitability Commercial Banks in Kenya. Economics and Finance Review, 1(5), $01-30$.

17.Onyango, J. (2016). The effect of external financing on the growth of savings and credit cooperatives wealth in Nairobi County, Kenya (unpublished master's project). United States International University, Kenya

18. Ratemo, J. (2015). Kenyan SACCOs riding on innovation to attract customers. Biztech Africa. Retrieved from: http://www.biztechafrica.com/article/kenyan-SACCOs-riding-innovation-attractcustomers/10407/

19.Sebhatu, K. T. (2012). Management of savings and credit cooperatives from the perspective of outreach and sustainability: Evidence from Southern Tigrai of Ethiopia.Research Journal of Finance and Accounting, 2(7-8), 10-23.

20.Wangai, D. K., Bosire, N., Gathogo, G. (2012). Impact of Non-Performing Loans on Financial Performance of Microfinance Banks in Kenya: A Survey of Microfinance Banks in Nakuru Town. International Journal of Science and Research (IJSR) ISSN (Online): 2319-7064 